\title{
Effects of nitrogen on crop development and grain growth of winter wheat in relation to assimilation and utilization of assimilates and nutrients
}

\section{J. H. J. Spiertz * and J. Ellen}

Department of Field Crops and Grassland Husbandry, Agricultural University, Wageningen, the Netherlands

Accepted: 11 April 1978

Key words: nitrogen supply, leaf area, grain number, grain growth, carbohydrate reserves, uptake of nutrients, distribution of nutrients, harvest index, winter wheat

\section{Summary}

Grain growth and yield components of winter wheat (cv. Lely) were studied in a field experiment in 1976 with four regimes of nitrogen dressing $(50,100,100+50$ and $100+100 \mathrm{~kg} \mathrm{~N} \mathrm{ha}^{-1}$ ). Growing conditions were characterized by a high level of solar radiation, warmth, ample nutrient supply and no damage by diseases.

Nitrogen raised grain number per $\mathrm{m}^{2}$ from 16700 to 20600 and grain yield from 640 to $821 \mathrm{~g}$ dry weight $\mathrm{m}^{-2}$. Grain growth duration was short, due to warmth, but the rate of the grain filling was very high: from 24.0 to $29.2 \mathrm{~g} \mathrm{~m}^{-2}$ day-1 during the effective grain-filling period. A high grain yield was associated with a high nitrogen percentage of the grains, wich resulted in a grain protein yield ranging from 63.8 to $107.1 \mathrm{~g} \mathrm{~m}^{-2}$ with an increased nitrogen dressing from 50 to $200 \mathrm{~kg} \mathrm{ha}^{-1}$.

The carbohydrate demand of the grains was provided by current photosynthesis and relocation of stem reserves. The latter was reflected in a decline of the stem weight after the mid-kernel filling stage. Nitrogen and phosphorus demand of the grains were supplied by withdrawal from the vegetative organs (leaves, stem, chaff) and to a large extent by post-floral uptake and assimilation.

Under the prevailing growing conditions the grains turned out to be very strong sinks for carbohydrate, nitrogen and phosphorus as shown by the harvest-indices. Additional nitrogen dressings increased the harvest-indices of dry matter, nitrogen and phosphorus from 0.40 to 0.48 , from 0.75 to 0.81 and from 0.91 to 0.93 , respectively.

It was suggested that a more restricted vegetative crop development at high nitro*Present address: Centre for Agrobiological Research (CABO), P.O. Box 14,
6700 AA Wageningen, the Netherlands. 
gen levels and a longer duration of root activity, photosynthesis and grain growth after anthesis would considerably favour grain yield.

\section{Introduction}

Grain yield of wheat is a function of the number and growth rate of kernels per unit ground area. The growth rate is the result of production of assimilates and storage of carbon and nitrogen compounds in the developing grains. The carbon supply depends mainly on the green area duration and the net photosynthesis of leaves, glumes and stem after anthesis (Evans \& Wardlaw, 1976; Stoy, 1975). The nitrogen supply depends on the relocation of reserves in the vegetative organs to the grains and on the uptake and reduction of nitrate during the grain filling periode (Austin et al., 1976; Dalling et al., 1976; Campbell et al., 1977b).

The aim of this experiment was to study the effect of various levels of nitrogen dressing and disease control on plant growth and crop development (number of culms, grain number, leaf area), on the post-floral economy of carbohydrates and nutrients $(\mathrm{N}, \mathrm{P}$ and $\mathrm{K}$ ) and on the grain growth pattern of winter wheat under optimal growing conditions in the field.

\section{Methods}

The experiment was carried out on the experimental farm of the Agricultural University, located in the Flevopolder. The type of soil was marine clay of the following characteristics: clay content $(<16 \mu \mathrm{m}) 45 \%$; organic matter $2.8 \%$; $\mathrm{pH}-\mathrm{KCl} 7.3 ; \mathrm{CaCO}_{3} 10.0 \%$; K. value $22 ; \mathrm{K}-\mathrm{HCl} 24 ; \mathrm{Pw}$ value 23 . Before sowing $250 \mathrm{~kg}$ per ha of $43 \%$ superphosphate was applied; potassium was omitted since it was already abundant in the soil. Nitrate-nitrogen, available in the soil layer of $0.75 \mathrm{~m}$ depth, amounted to approximately $80 \mathrm{~kg} \mathrm{~N}$ per ha at the end of February 1976. The mineralization of nitrogen in the soil during the growing season of 1976 was relatively high. The wheat crop was grown in a nine-year rotation with seed potatoes as previous crop.

Sowing of the cultivar Lely was done on 23 October 1975 with a seed rate of 400 kernels per $\mathrm{m}^{2}$. Nitrogen was applied as split dressing with the following treatments (in $\mathrm{kg} \mathrm{N} \mathrm{ha}^{-1}$ ):

$\begin{array}{cccc} & 16 \text { March } & 20 \text { May } & \text { Total } \\ \mathrm{N}_{1} & 50 & 0 & 50 \\ \mathrm{~N}_{2} & 100 & 0 & 100 \\ \mathrm{~N}_{3} & 100 & 50 & 150 \\ \mathrm{~N}_{4} & 100 & 100 & 200\end{array}$

The experiment consisted of a completely random block design with four nitrogen and four fungicide treatments and with four replicates. The fungicide sprayings were carried out at stage F5-6, at F10.3 and at both stages with $4 \mathrm{~kg} \mathrm{ha}^{-1}$ of Bavistin $\mathrm{M}$ which contained $240 \mathrm{~g}$ carbendazim and $1700 \mathrm{~g}$ maneb as active substance. 


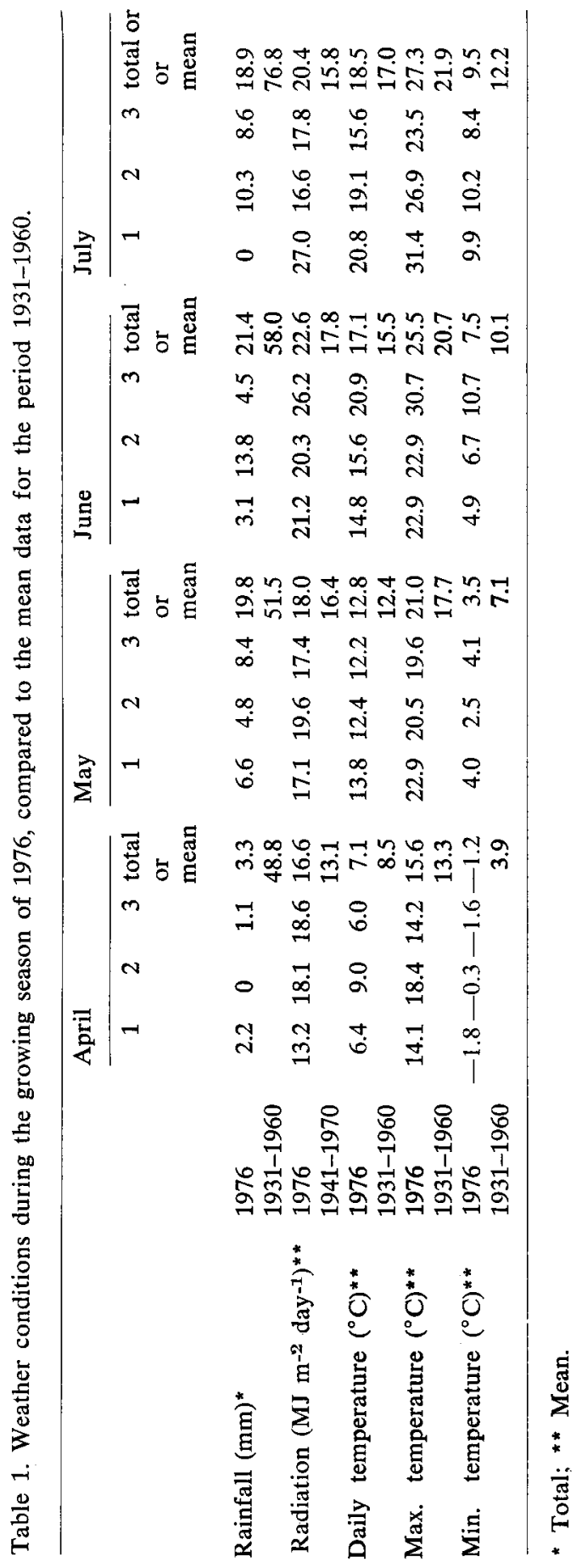


Weeds were controlled by spraying with 4 litres MCPP per ha at the end of April. This spraying was combined with the application of 2 litres chlormequat (CCC) per ha.

The individual plots had an area of $6 \times 20 \mathrm{~m}^{2}$ with row widths of $15 \mathrm{~cm}$. An inner strip of $3 \mathrm{~m}$ was reserved for the combine harvest. Sampling during the growth period were carried out in the inner rows of the border strips, each consisting of 10 rows of $20 \mathrm{~m}$ length.

\section{Observations}

Measurements of crop growth and plant development were carried out on 27 April, 18 May, 1 June and weekly from 15 June onwards. The area sampled at these intermediate harvests amounted to $0.30 \mathrm{~m}^{2}(=4$ rows of $0.50 \mathrm{~cm})$ per plot. After determining fresh weight and tiller number the samples were sub-divided for measurements of leaf area per leaf layer and dry weight of the various parts of the culm. For the chemical analyses small samples were prepared. All samples were dried at $70{ }^{\circ} \mathrm{C}$ (for details, see Spiertz, 1977). Chemical analyses of nitrogen, phosphorus and potassium were done by the Department of Soils and Fertilizers of the Agricultural University.

The light interception by the crop was measured in all plots perpendicular to the rows with an integrating photometer $(0.4-0.7 \mathrm{~nm})$ of one metre length.

In 1976 the growing season started relatively cold, sunny and dry in April (see Table 1). After anthesis, on 12 June, the weather became much warmer and dryer than average, especially from a fortnight after anthesis onwards. The crop senesced very rapidly therefore and the grain filling period was comparatively short. In spite of this extreme weather conditions there was ample water available at $60 \mathrm{~cm}$ depth in this polder soil; thus the early ripening was obviously not caused by water shortage.

Disease infections were very limited during this growing season. Only during the early stages of crop development Septoria tritici could be observed. From the fungicide treatments it appeared that no damage of leaf and ear diseases had occurred.

\section{Results}

The data are presented without considering fungicide treatments. At intermediate harvests the number of replicates amounted to four, whilst at the harvests of 27 and 29 July a complete analysis of variance was computed (Table 2).

\section{Canopy structure, yield and yield components}

Plant density was quite high, about 344 plants per $\mathrm{m}^{2}$, due to the high seed rate and the mild winter. Tillering amounted on avarage to about 2.5 and 4.1 tillers per plant on 6 and 27 April, respectively. The maximum tiller number was achieved at the end of April and amounted to 1410 per $\mathrm{m}^{2}$. There was no significant difference in tiller density between the nitrogen treatments. The weather in May did not favour leaf and stem elongation of the wheat plant, so the crop remained 


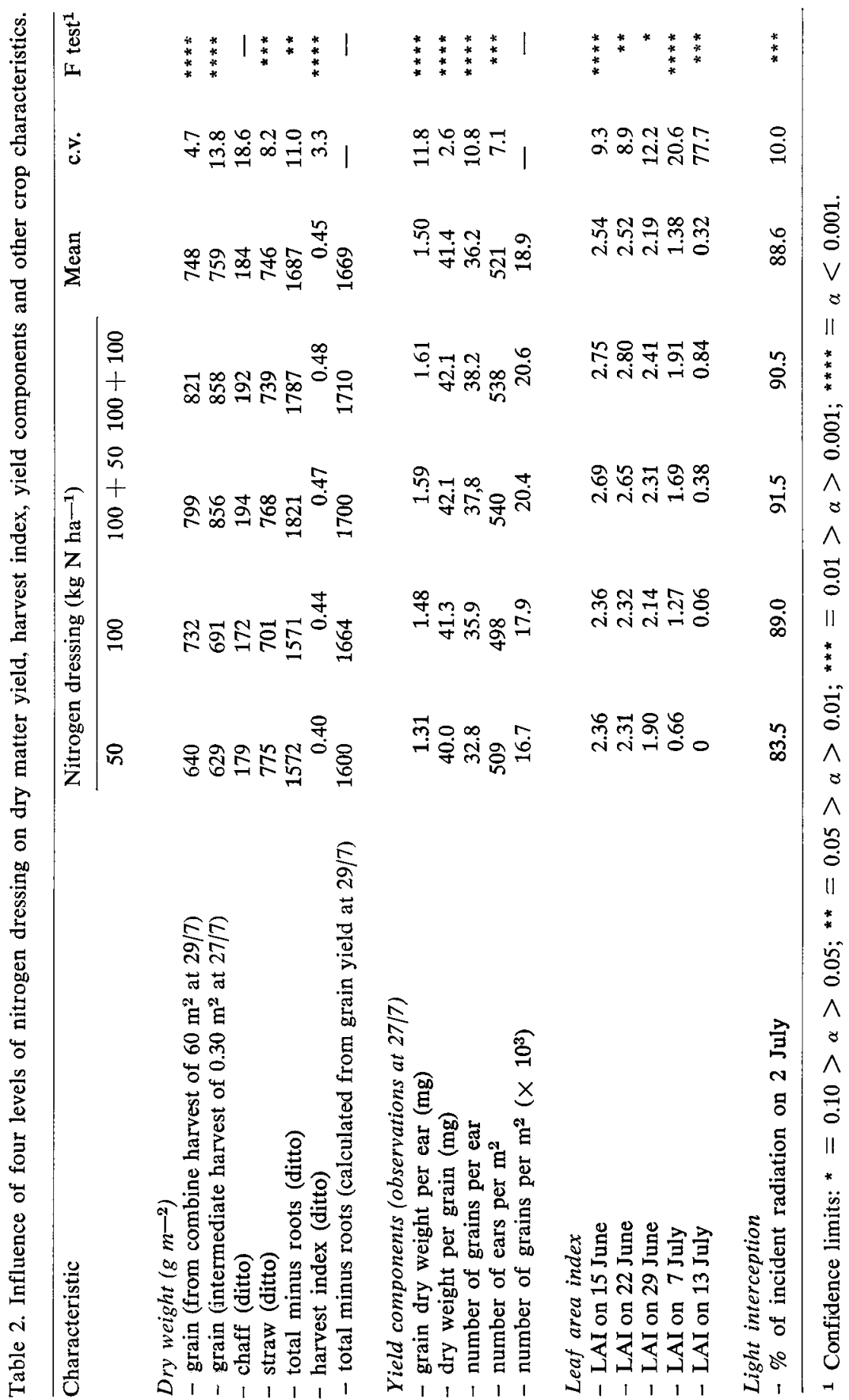




\section{J. H. J. SPIERTZ AND J. ELLEN}

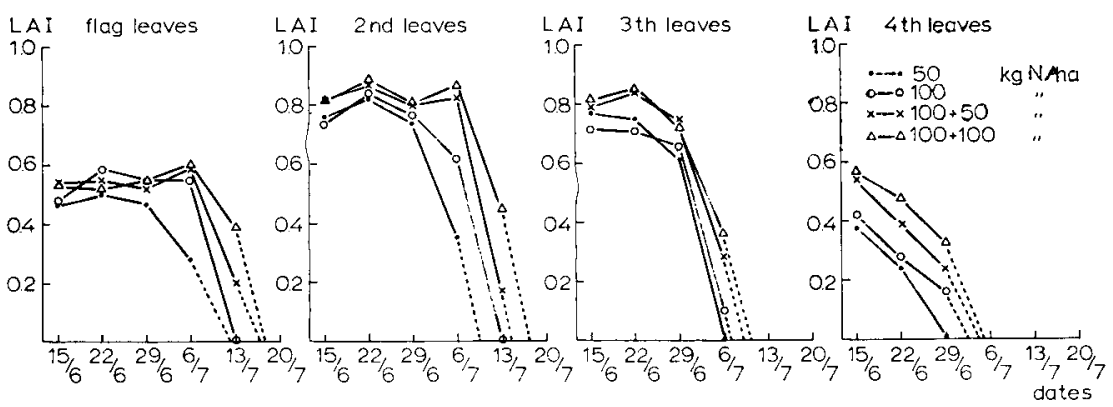

Fig. 1. Leaf area index per leaf layer after anthesis at four levels of nitrogen dressing.

short and stiff-strawed. The areas of the leaves were much smaller than is normally expected; the flag leaf in particular was very short (Fig. 1). The area of the upper leaves remained rather constant for two weeks after anthesis; from then on senescence proceeded very rapidly, especially with the lower nitrogen treatments. The difference in the duration of the green area between the plots with 50 and $200 \mathrm{~kg} \mathrm{~N} /$ ha was about seven days.

Despite the low leaf lamina area index, light interception by the crop 2 weeks after anthesis ranged from 83.5 to $91.5 \%$ of the incident visible radiation (Table 2 ). Stems and ears therefore must also have intercepted a large amount of radiation. The contribution of the leaf laminae to the total (one-sided) green area amounted to about $40 \%$.

The positive response of grain yield to a rise in nitrogen supply must be attributed mainly to an increase in the number of kernels per ear (Table 2). This number raised from 32.8 to 35.9 kernels per ear by increasing the nitrogen dressing on 16 March from 50 to $100 \mathrm{~kg} \mathrm{ha}^{-1}$. An additional nitrogen dressing of $50 \mathrm{~kg} \mathrm{ha-1}$ during the boot stage gave an extra response of about two kernels per ear. Dry weight per grain increased from 40.0 to $42.1 \mathrm{mg}$ as nitrogen dressings were raised from 50 to $100+50 \mathrm{~kg} \mathrm{~N}^{-1}$, respectively. The number of ears was also increased by extra nitrogen, but to a lesser extent than the number of kernels per ear. Grain yield was therefore mainly determined by the number of kernels per $\mathrm{m}^{2}$. An increase in the number of kernels per $\mathrm{m}^{2}$ from 16700 to 20600 corresponded with grain yields of 640 and $821 \mathrm{~g}$ dry weight per $\mathrm{m}^{2}$ at the final harvest (29 July).

Dry weights of straw and chaff were determined on samples from an intermediate harvest of $0.30 \mathrm{~m}^{2}$ on $27 \mathrm{July}$. The nitrogen treatments were only partly reflected in straw and total dry matter yield, in spite of a clear response of the grain yield to nitrogen. For this reason the total dry weight was also calculated from the grain yield of an area of $60 \mathrm{~m}^{2}$ by means of the harvest index. The total dry matter yield then increased from 16.0 to 17.1 tons with nitrogen dressings of 50 and $100+$ $100 \mathrm{~kg} \mathrm{ha}^{-1}$ respectively. This increase was less than the rise in the total grain weight, which indicates an improved translocation of assimilates from the vegetative parts of the wheat plant to the grains with increased nitrogen supply. Thus 
the range from 0.40 to 0.48 for the harvest index was mainly brought about by the differences in grain yield.

When individual treatments instead of the whole range of nitrogen dressings are compared, Student's test (confidence level of $50 \%$ ) did not show any significant differences in grain yield and yield components between $100+50$ and $100+$ $100 \mathrm{~kg} \mathrm{~N}$ ha $^{-1}$. Thus the maximum grain yield, as far as nitrogen was concerned, was almost completely realized with a split dressing of $100+50 \mathrm{~kg} \mathrm{~N}^{\mathrm{N}} \mathrm{ha}^{-1}$. A further increase of nitrogen did not raise the yield substantially. The effect of nitrogen on the uptake of nutrients and on the chemical composition of the various parts of the wheat plant are discussed further on in the paper.

\section{Rate and duration of grain growth}

Grain growth of this winter wheat crop was characterized by a short growth period. The effective grain-filling period lasted about 4 weeks, while the period from anthesis to maximum grain weight amounted to about 5 weeks. The period with a high rate of grain growth ended before mid-July, followed by only a small increase in grain weight later on.

Despite the very short kernel-filling period grain yields turned out to be quite high. So the rate of grain growth must have been exceptionally fast. From the end of anthesis (15/6) until the stage of maximum kernel weight $(20 / 7)$ the daily grain growth ranged from 1.13 to $1.19 \mathrm{mg}$ dry weight per kernel, from 33.4 to 41.1 mg dry weight per ear and from 19.0 to $24.0 \mathrm{~g} \mathrm{~m}^{-2}$, due to an increased nitrogen dressing (Fig. 2).

From approximately 29 June to 6 July, the growth rate of individual grains was hardly affected by nitrogen and amounted on average to $2.5 \mathrm{mg} \mathrm{kernel}^{-1} \mathrm{day}^{-1}$. After the midkernel filling stage late nitrogen treatments increased grain growth rate from 0.78 to $1.09 \mathrm{mg} \mathrm{kernel}^{-1}$ day-1. $^{-1}$.

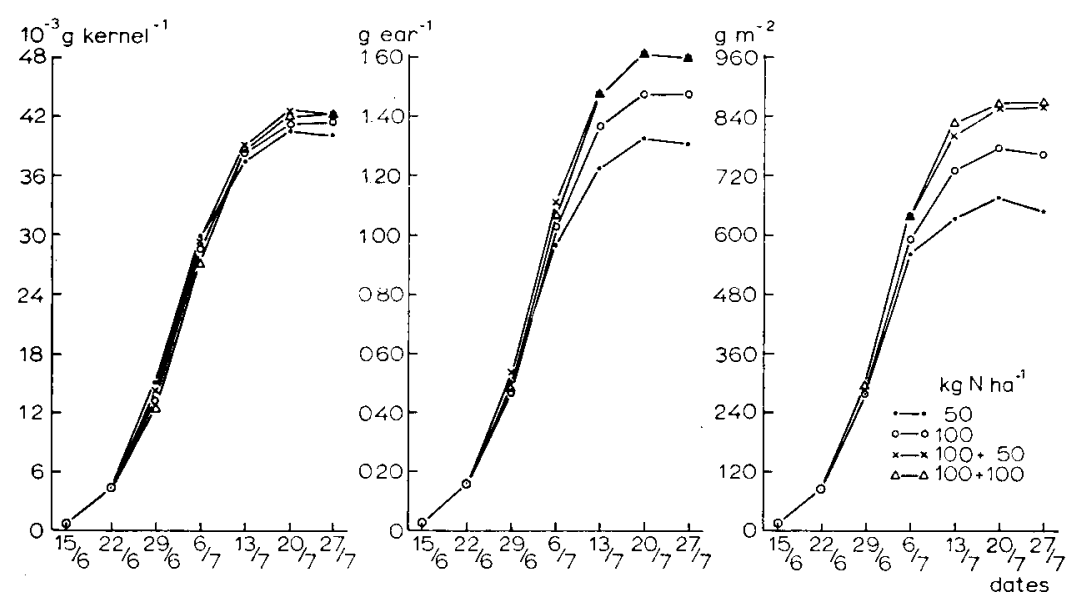

Fig. 2. Growth curves of grain dry weight per kernel, per ear and per $m^{2}$ at four levels of nitrogen dressing. 


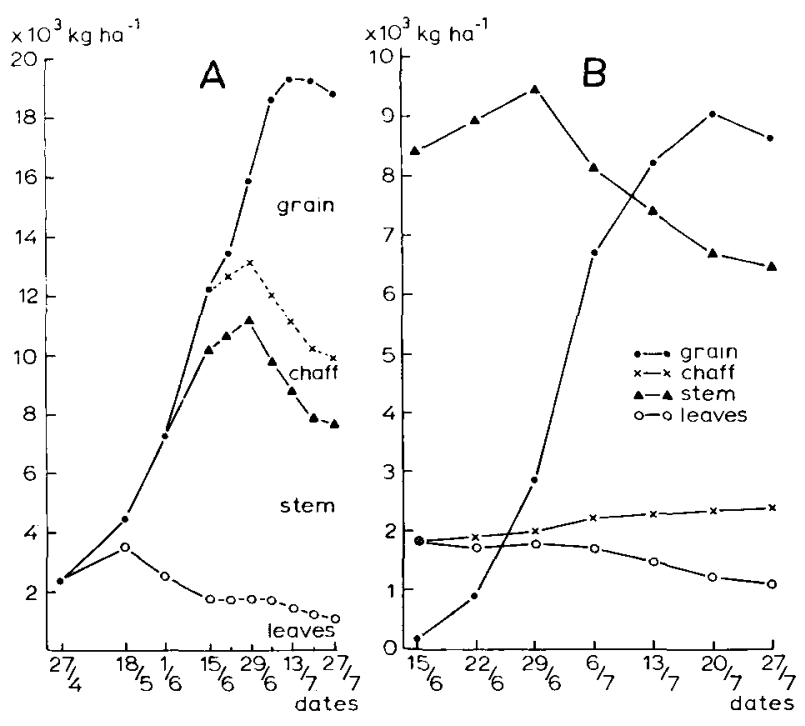

Fig. 3A. Distribution pattern of dry weight for the above-ground parts of the wheat plant at nitrogen dressing of $100+100 \mathrm{~kg} \mathrm{~N} \mathrm{ha}^{-1}$.

Fig. 3B. Course of dry weights of grain, chaff, stem and leaves after anthesis at a nitrogen dressing of $100+100 \mathrm{~kg} \mathrm{~N} \mathrm{ha}^{-1}$.

As additional nitrogen increased both the number of kernels per $\mathrm{m}^{2}$ and the growth rate per kernel, more assimilates must have been made available from grain growth either by an increased photosynthetic production or by an improved utilization of stored assimilates in the stem. In fact, additional nitrogen promoted photosynthetic production, as shown by the increase in the total matter yield of the crop (Table 2). Nevertheless a gap in the dry weight balance for the grains existed, which can only have been filled up by an increased relocation of assimilates from the stem to the grains.

\section{Dry matter distribution and carbohydrate reserves}

There were only smal changes in the dry weights of the leaf blades and the chaff from flowering onwards, but stem weight increased during the two weeks after anthesis, succeeded by a sharp decline (Fig. 3). Thus initially the production of assimilates by current photosynthesis was greater than the demand for grain growth. The decrease in stem weight took place simultaneously with the start of a hot spell, which obviously accelerated grain growth. The loss of stem weight amounted, within a 3-week period, to 3360 and $2760 \mathrm{~kg} \mathrm{ha}^{-1}$ with 50 and 200 $\mathrm{kg} \mathrm{N} \mathrm{ha-1,} \mathrm{respectively} \mathrm{(Table} 3$ ). It may be assumed, that a part of the loss in stem weight was caused by respiration, but relocation of assimilates to the grains and the roots may also have contributed to it. Especially during the latter part of the grain filling period, when grain growth coincides with a decline in current photosynthesis of senescing green organs, relocation of stem reserves may have been important source of assimilates. 
Table 3. Losses of dry weight and water-soluble carbohydrates (w.s.c.) from the stem during the grain-filling period.

\begin{tabular}{|c|c|c|c|c|c|c|}
\hline \multirow{2}{*}{$\begin{array}{l}\text { Nitrogen } \\
\text { dressing } \\
\text { (kg N ha-1) }\end{array}$} & \multicolumn{2}{|l|}{29 June } & \multicolumn{2}{|l|}{20 July } & \multicolumn{2}{|c|}{ Loss from $29-6$ to $20-7$} \\
\hline & $\begin{array}{l}\text { mg per } \\
\text { culm }\end{array}$ & $\mathrm{g} \mathrm{m}^{-2}$ & $\begin{array}{l}\text { mg per } \\
\text { culm }\end{array}$ & $\mathrm{g} \mathrm{m}^{-2}$ & $\begin{array}{l}\text { mg per } \\
\text { culm }\end{array}$ & $\mathrm{g} \mathrm{m}^{-2}$ \\
\hline \multicolumn{7}{|c|}{ stem dry weight } \\
\hline 50 & 1.91 & 972 & 1.25 & 636 & 0.66 & 336 \\
\hline $100+100$ & 1.75 & 928 & 1.23 & 652 & 0.52 & 276 \\
\hline \multicolumn{7}{|l|}{ w.s.c. content } \\
\hline 50 & 0.63 & 323 & 0.08 & 38 & 0.55 & 285 \\
\hline $100+100$ & 0.47 & 249 & 0.05 & 26 & 0.42 & 223 \\
\hline
\end{tabular}

Changes in dry weight of the stems are mainly caused by changes in the non-structural carbohydrates. The influence of nitrogen on the percentage and amount of water-soluble carbohydrates in stem, leaves and grain is shown in Fig 4. Generally the carbohydrate percentages are lowered by an increased nitrogen supply. However, the pattern of accumulation and decrease of carbohydrate reserves in the vegetative organs during the post-floral period is more interesting. It gives more insight into the reserves available for energy-requiring processes (e.g. respiration) and for grain growth.

The water-soluble carbohydrates (w.s.c.) accumulated in the stem up to a fortnight after anthesis. The w.s.c. percentage at that stage ranged from 26.8 to 33.2 in
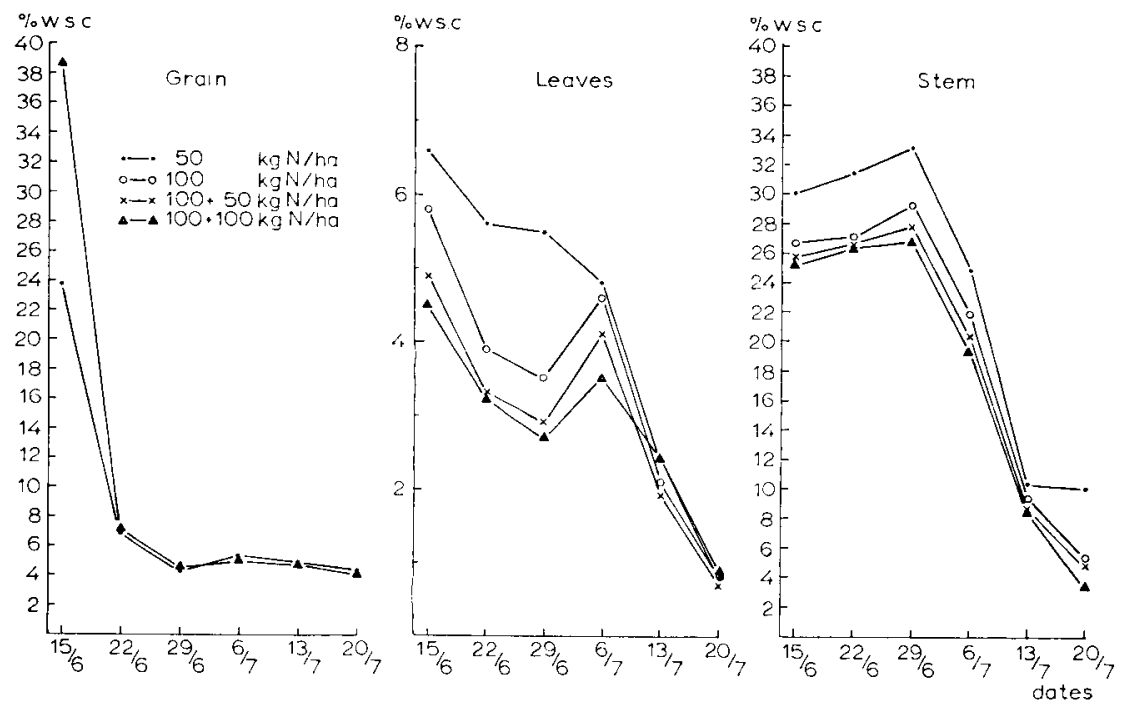

Fig. 4. The water-soluble carbohydrate content of grain, leaves and stem after anthesis at four levels of nitrogen dressing. 

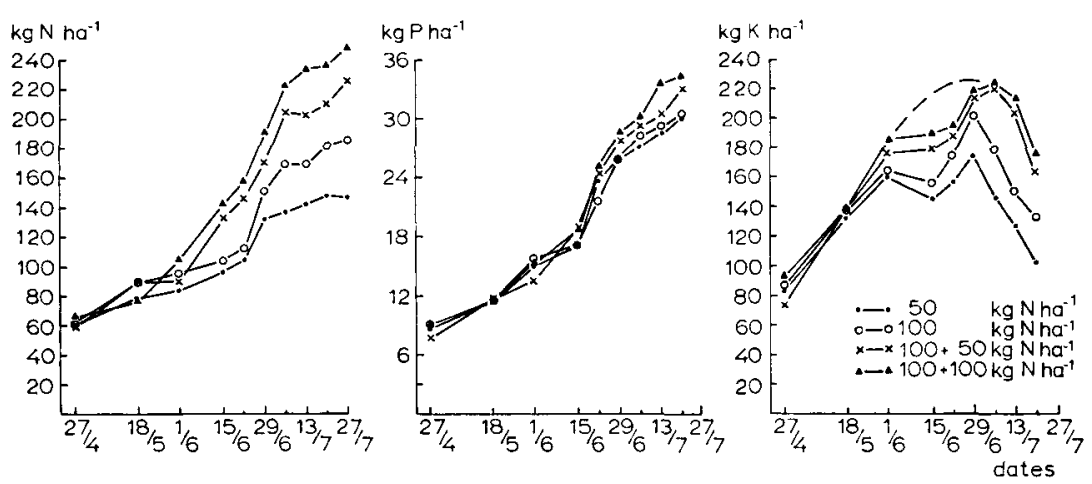

Fig. 5. Amounts of nitrogen $(\mathrm{N})$, phosphorus $(\mathrm{P})$ and potassium $(\mathrm{K})$ in the wheat culm during the growing season at four levels of nitrogen dressing.

the stem, from 2.7 to 5.5 in the leaves and amounted to $5 \%$ in the grains for nitrogen dressings from 200 to $50 \mathrm{~kg} \mathrm{~N} h a-1^{-1}$. The storage function of the stem is also strongly expressed by the quantity of w.s.c. available in it. This quantity increased for two weeks after anthesis from for two weeks after anthesis from about 250 to about $280 \mathrm{~g} \mathrm{~m}^{-2}$, followed by a sharp decrease from 280 to $60 \mathrm{~g} \mathrm{~m}^{-2}$ after the mid-kernel filling stage. The w.s.c. quantities in the other organs are on a lower level: at anthesis for leaves, chaff an grain about $9.5,12.5$ and $5.0 \mathrm{~g} \mathrm{~m}^{-2}$, respectively. During the post-floral period the carbohydrate quantities of the leaves did not decrease linearly, but there was a second peak 3 weeks after anthesis. This peak coincided with a decline in the rate of grain growth. The amount of w.s.c. in the grains increased up to $35.0 \mathrm{~g} \mathrm{~m}^{-2}$.

These data show that the w.s.c. reserves in the stem play an important role as a carbohydrate source for the grains, when the production of assimilates by current photosynthesis is reduced, due to progressive senescence of the photosynthetic tissues.

\section{Uptake and distribution of nitrogen, phosphate and potassium}

The uptake of nitrogen, phosphorus and potassium showed a peculair pattern, which was characterized by a temporary slow-down of nitrogen and potassium uptake during the heading phase followed by an accelerated assimilation of nutrients during the post-floral period (Fig. 5). This phenomenon may be associated with the cool, dry weather during the pre-anthesis period, interrupted by a sharp rise in temperature after anthesis and a significant amount of rainfall $(18.3 \mathrm{~mm})$ one week after anthesis.

The maximum nitrogen $(\mathrm{N})$ and phosphorus $(\mathrm{P})$ yields of the above-ground parts of the plant were attained at ripening and ranged from 147 to $248 \mathrm{~kg} \mathrm{ha}^{-1}$ and from 30 to $35 \mathrm{~kg} \mathrm{ha}^{-1}$ with 50 and $200 \mathrm{~kg}$ nitrogen dressing, respectively. The potassium yield reached maximum levels at the mid-kernel filling stage and ranged from 175 to $223 \mathrm{~kg} \mathrm{ha}^{-1}$ (Fig. 5). The highest rates of uptake amounted to 4.6, 0.4 and $2.4 \mathrm{~kg} \mathrm{ha}^{-1}$ day-1 of nitrogen, phosphorus and potassium, respectively, 
during the kernel-filling period. The assimilation of these nutrients by the grains amounted during the same period to $7.6,1.4$ and $1.1 \mathrm{~kg} \mathrm{ha}^{-1}$ day-1, with the highest nitrogen dressing. Thus the demand of the grains, as far as nitrogen and
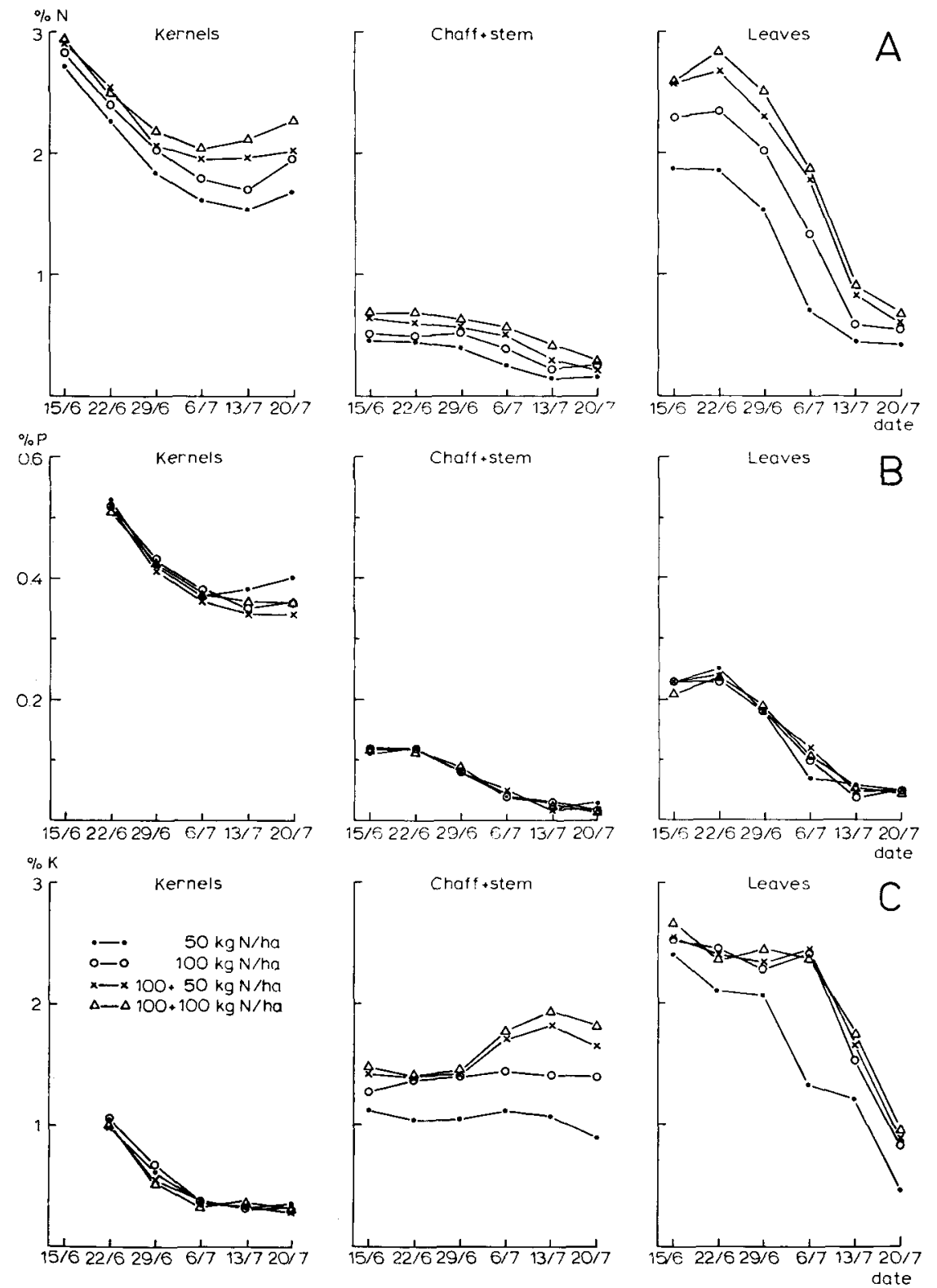

Fig. 6. Effects of the nitrogen dressings on nitrogen (A), phosphorus (B) and potassium (C) percentages of the grains, stem and leaves after anthesis. 

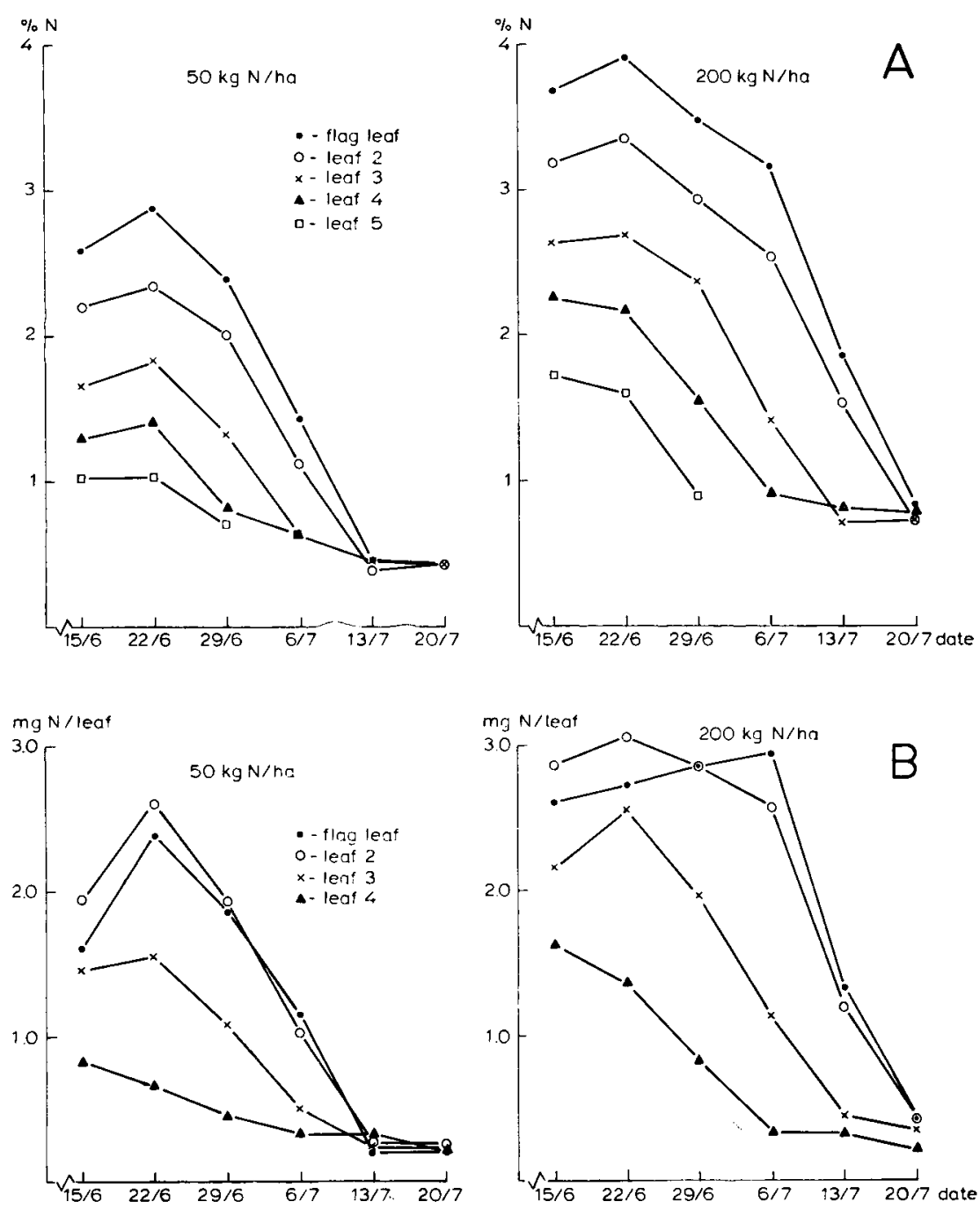

Fig. 7. Post-floral nitrogen percentages (A) and contents (B) of the various leaf layers at 50 and $200 \mathrm{~kg} \mathrm{~N}$ ha-1. $^{\circ}$.

phosphorus are concerned, was considerably higher than the post-floral uptake by the plant. From these figures it follows that a supply from the vegetative parts was made available to the grains.

The pattern of nitrogen, phosphorus and potassium contents, expressed as percentages of the dry weight of leaves, stem and grain, is shown in Fig. 6. On average the nitrogen percentages of the leaves decreased during the post-floral period from 2.4 to 0.6 , but there were large diffencences due to nitrogen level and leaf layer. 
The nitrogen concentration of the other vegetative above-ground organs - stem, rachis and chaff - also increased with additional nitrogen supply. The nitrogen concentration of the stem increased from 0.45 to $0.70 \%$ and of the chaff (including the rachis) from 1.48 to $1.69 \%$. These nitrogen percentages decreased linearly during the grain-filling period to levels of about $0.25 \%$ and $0.50 \%$ for the stem and chaff, respectively.

The nitrogen percentage of the grain decreased during the first three weeks after anthesis from about 2.80 to $1.80 \%$ and rose again at the end of the grain-filling period to about $2.09 \%$. As a result of the nitrogen dressings the nitrogen contents of the grain at ripening ranged from 1.72 to $2.25 \%$.

The nitrogen treatments hardly affected the phosphorus content of the various components, but increased the potassium content of the vegetative parts of the culm. Nitrogen applied at Feekes stage 8 raised the potassium content of the stem, but not of the leaves. The potassium content of the grains was not affected by nitrogen at all.
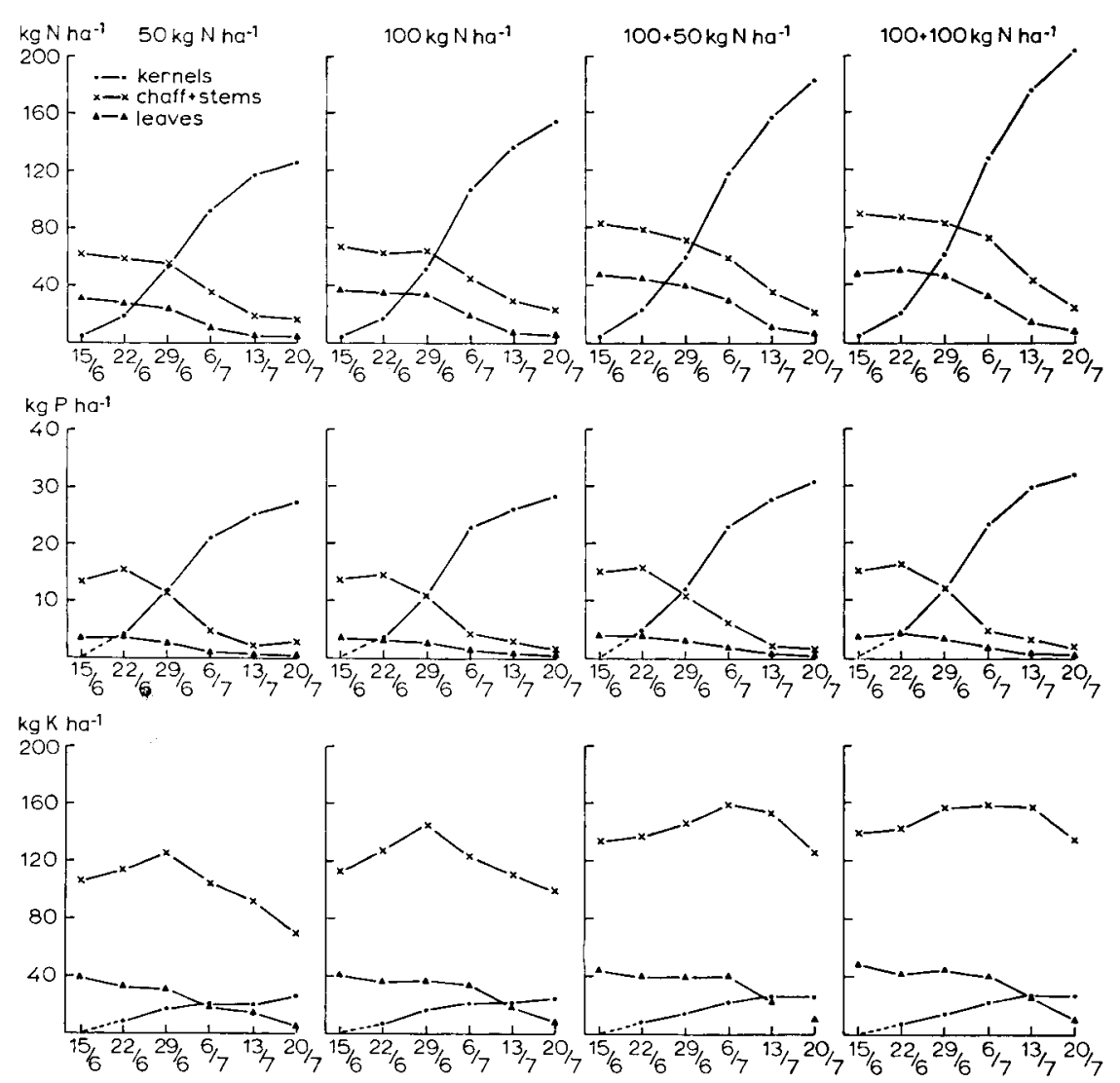

Fig. 8. Distribution pattern of nitrogen (A), phosphorus (B) and potassium (C) in the wheat culm after anthesis at four levels of nitrogen dressing. 


\section{J. H. J. SPIERTZ AND J. ELLEN}

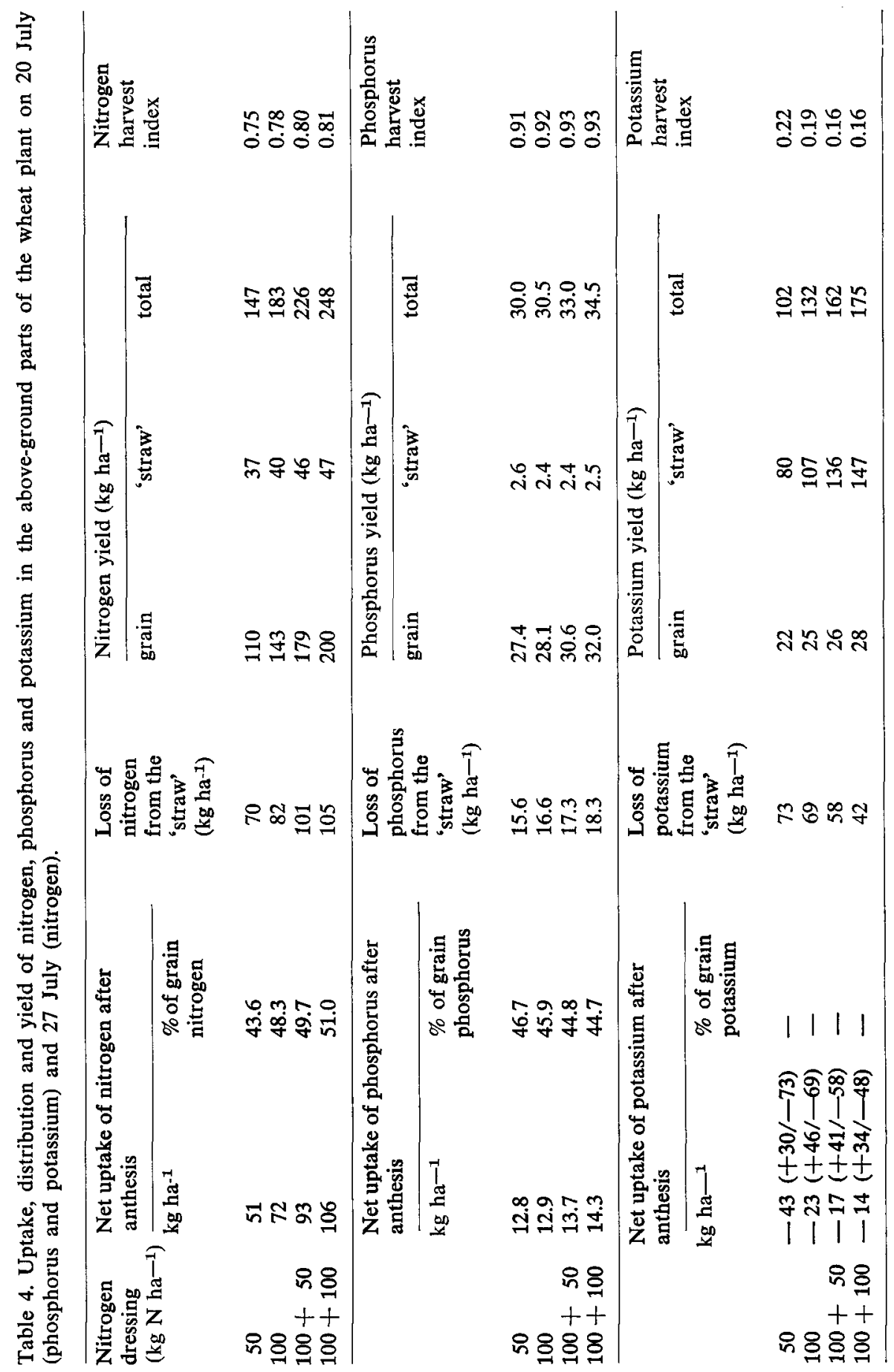

Neth. J. agric. Sci. 26 (1978) 
A rise in the nitrogen dressing from 50 to $100+100 \mathrm{~kg} \mathrm{~N}$ ha-1 increased the nitrogen percentages of the leaves: for the flag leaf from 2.87 to $3.90 \%$, for the penultimate leaf from 2.34 to $3.35 \%$, for the third leaf from 1.82 to $2.68 \%$ and for the fourth leaf from 1.40 to $2.16 \%$ at 10 days after anthesis (Fig. 7A). These differences in nitrogen percentages persisted during the grain filling period until the leaves senesced. Even then a small difference in nitrogen concentration remained. The pattern of nitrogen content of the leaves clearly shows that additional nitrogen delayed senescence of the top leaves by 8 to 10 days and considerably increased the amount of nitrogen available in the leaves for re-distribution to the grains (Fig. 7B).

The distribution patterns of nitrogen, phosphorus and potassium in the wheat culm are shown in Fig. 8 and Table 4. During the post-floral period the grains are a large sink for nitrogen and phosphorus. The supply from the reserves stored in the vegetative parts of the culm at anthesis did not fulfil the demand of the grains. Therefore, the nitrogen and phosphorus yields could not have been realized but for a substantial contribution through uptake during the grain-filling period. The amount of nitrogen uptake after anthesis corresponded on average to $48 \%$ of the nitrogen yield of the grains. Thus the reserves in the vegetative organs contributed only about $52 \%$ of the nitrogen stored in the grain. The same pattern was established with phosphorus: $45 \%$ was contributed by uptake after anthesis and $55 \%$ by relocation from the vegetative organs. The rachis and chaff contained relatively more phosphorus than nitrogen at anthesis and also acted as an important source of phosphorus for the grains. The distribution of the nutrients in the wheat culm expressed as harvest index is presented in Table 4; this parameter is calculated as the ratio of the nutrient amount in the grain and in the above-ground part of the culm. The harvest index of phosphorus ranged from 0.91 to 0.93 and of nitrogen from 0.75 to 0.81 . Late nitrogen applications promoted the uptake of nutrients during the kernel-filling period and consequently raised these harvest indices.

The potassium economy of the wheat shoot was quite different from that of nitrogen and phosphorus. Although potassium uptake by the grain was small, potassium contents of the stem and the leaves dropped from about the mid-kernel filling stage onwards. The main storage centre for potassium was the stem (including the leaf sheaths); with lower nitrogen applications potassium accumulated in the stem for two weeks after anthesis, followed by a linear decrease until maturity. With additional late nitrogen applications the potassium accumulation in the stem continued for four weeks after anthesis, followed by a short period of potassium loss from the stem. Generally, the balance between uptake and loss of potassium in the vegetative parts of the culm after anthesis seemed to be more negative with lower nitrogen applications (Table 4). Thus an increased nitrogen dressing greatly promoted the potassium yield in the vegetative parts of the culm; the potassium content of the grain responded less to nitrogen. The potassium harvest index decreased therefore with a higher nitrogen supply. 


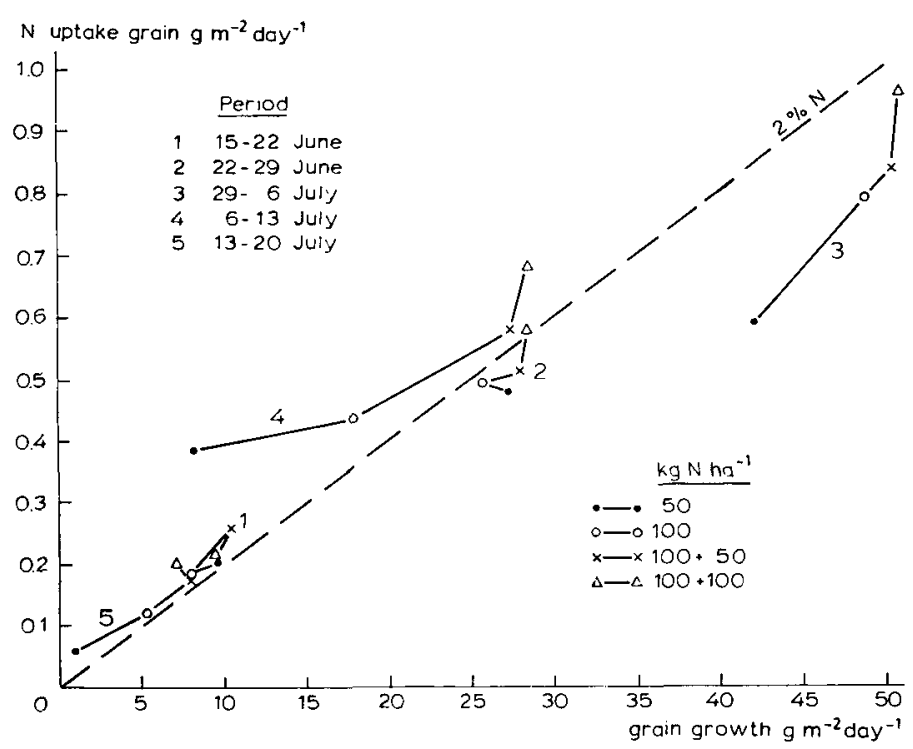

Fig. 9. The relation between grain growth and nitrogen uptake at weekly intervals with four nitrogen dressings.

Interrelationship between carbohydrate and nitrogen metabolism

Carbohydrate and nitrogen supply to the grain are partly interrelated because nitrogen translocated from the vegetative parts to the grains consist mainly of amino acids.

The relationship between the rate of grain growth and the rate of nitrogen uptake is shown in Fig. 9. Nitrogen dressings hardly affected the nitrogen uptake in the first two weeks after anthesis, but had a considerable effect during the third and fourth weeks. Thus the regulation of the nitrogen uptake by the grain was not under genetic control alone but also depended on the nitrogen supply, whether by transfer from the vegetative parts or by direct contribution from the roots. The greatest demand of the grains for nitrogen occurred during the mid-kernel filling phase. Then the nitrogen uptake ranged from 5.7 to $9.6 \mathrm{~kg} \mathrm{ha}^{-1}$ day-1 with 50 and $200 \mathrm{~kg} \mathrm{~N}^{-1} \mathrm{~d}^{-1}$ dressing, respectively.

Not only is the supply of carbon and nitrogen to the grain interrelated, but also the loss of these components from the vegetative organs: leaves, stem and chaff. Assuming that the nitrogen was translocated as amino acids containing $16 \%$ nitrogen (Austin et al., 1977), the losses of carbohydrate associated with the export of nitrogen can be calculated. The total loss of nitrogen from the vegetative parts of the plant ranged within the applied nitrogen dressings from 70 to $105 \mathrm{~kg} \mathrm{~N}$ $\mathrm{ha}^{-1}$ (Table 4), which corresponded to a dry matter loss from 437 to $656 \mathrm{~kg}$ $\mathrm{ha}^{-1}$. Stem and leaves contributed equally, each about $38 \%$, to this loss of nitrogen; the remaining part, about $24 \%$, came from the chaff. The dry weight loss of the stem by nitrogen compounds contributed only slightly (from 6 to $9 \%$ ) to the total losses, but nitrogen compounds accounted for about $40 \%$ of the weight 
loss of the leaves.

When there is simultaneous import and export of nitrogen compounds in the vegetative organs, then the estimates are only related to the net differences in the amount of stored nitrogen. It is possible that more nitrogen passes through the vegetative parts (e.g. leaves) during grain filling, which implies a higher dry weight loss associated with nitrogen assimilation and relocation.

\section{Discussion}

The weather conditions during the growing season of 1976 were characterized by an exceptionally low rainfall and an exceptionally high level of radiation (Table 1). In April the cloudless sky caused frequent night frosts. Simulation studies of crop behaviour during April showed a negative water balance in the plants on many days (W. Dekkers, pers. commun., 1977). During May growing conditions were more favourable, although the relative humidity was low. Leaf growth and stem extension were relatively more reduced than dry weight increase. This resulted in short and stiff culms with small leaves, but also root growth may have been favoured.

The thorough study of interactions between soil moisture and fertilizer $\mathrm{N}$ by Campbell et al. (1977a) on wheat growth and grain production showed that the root distribution was affected by moisture and growth stage. They found that due to a hot and dry spell between booting and anthesis the crop depleted all available water in the soil region to $90 \mathrm{~cm}$ depth and from 45 to $75 \mathrm{~cm}$ depth with the dry and irrigated treatments, respectively. Thus even with an additional water supply there may be, under conditions of high evapotranspiration, soil moisture deficits in the regions with a high root density. Usually, more than half the root mass is located in the top $30 \mathrm{~cm}$ of the soil (Campbell et al., 1977). Under the conditions of 1976 the phenomenon of temporary water stress of the root system in the top layer of the soil might have occurred. This could also explain the reduction of nutrient uptake (and even loss) compared with dry matter increase during the dry period before anthesis.

The general response of the crop to warmth after anthesis, showed a pattern of grain filling similar to those found by various studies of temperature effects on grain growth in phytotron experiments (Sofield et al., 1974; Spiertz, 1974; Ford \& Thorne, 1975; Warrington et al., 1977). This pattern is characterized by the apparent absence of a lag period, a high grain growth rate of short duration and premature senescence of the plant. There was one major difference with these indoor experiments; the final grain size was less affected by warmth. This might be explained by the better supply of assimilates to the fast growing grains in the field experiments, due to the higher level of radiation, as compared to the conditions in phytotron experiments. Nevertheless lower temperatures during the grain-filling period would certainly have favoured the dry weight of the grains. If lowering of the temperature by 5 degrees kelvin would have been possible without changing the level of solar radiation, then the corresponding increase of the kernel weight could be estimated to be 15 to $20 \%$ according to the response curve to 


\section{J. H. J. SPIERTZ AND J. ELLEN}

temperature in phytotron experiments (Spiertz, 1977; Warrington et al., 1977). Analysis of nitrogen effects on the grain production pattern under these particular growing conditions showed that an increased nitrogen supply raised the number of kernels per ear. The effect of top dressings at the boot stage on grain number was striking. This positive response to a late nitrogen application was also found in previous experiments and is confirmed by long-term field experiments (Gliemeroth \& Kübler, 1977) under conditions of a low level of nitrogen mineralization and only inorganic fertilization. A more detailed study of nitrogen effects on spike fertility was done by Langer \& Lieuw (1973) with spring wheat grown in solution culture. They found that raising the nitrogen supply at the double-ridge stage increased the number of spikelets, and a high nitrogen level between floret initiation and ear emergence favoured the number of kernels per spikelet. In our experiment the number of spikelets per ear was not affected by raising the early dressing from 50 to $100 \mathrm{~kg} \mathrm{~N}^{-1}$, this was obviously due to an adequate supply of soil nitrogen. The number of spikelets per ear amounted on average to 22 and the number of kernels per spikelet ranged from zero (the basal and top spikelet) to about three (spikelets 7 to 9 in the central part of the ear). Thus the major part of the positive effect of additional nitrogen on the number of kernels per spikelet was attributable to greater grain numbers in the lower and central part of the ear. The considerable increase in grain number per ear combined with the relatively small positive effect of nitrogen on the number of ears per $\mathrm{m}^{2}$, resulted in an increase in grain number per $\mathrm{m}^{2}$ from 16700 to 20600 . The rise in grain yield was mainly attributable to the number of grains per $\mathrm{m}^{2}$. This agrees with the general view that under very sunny conditions and high temperatures the number of grains per unit ground area is a major component of grain yield (Biscoe \& Gallagher, 1977). Since final grain number was fixed soon after anthesis it may be concluded that the grain pattern of the individual kernels will be decisive for the grain yield.

Additional nitrogen affected both the growth duration and the growth rate of individual grains. However, with all nitrogen treatments the rate of grain growth was very high due to warmth. The growth rates during a seven-day period in the linear phase of grain filling amounted on average to $2.5 \mathrm{mg}$ kernel-1 day-1. This value is higher than the maximum rate of $2 \mathrm{mg}$ day-1 quoted for wheat in a recent review of literature (Evans \& Wardlaw, 1976). With the cultivar Maris Huntsman, however, Meredith \& Jenkins (1976) found a grain growth rate of $2.6 \mathrm{mg}$ day $^{-1}$ during 11 days and Gallagher et al. (1976) reported an increase in the rate of grain growth up to $2.11 \mathrm{mg}$ day $^{-1}$ during 14 days under the hot and sunny conditions of 1976 .

The proportionality between grain number and grain yield implies that the photosynthetic system of the plant has produced adequate amounts of assimilates to satisfy the demands of the grains. This assumption is supported by the storage of excess assimilates in the stem for two weeks after anthesis (Fig 3) and the high content of carbohydrates available in the stem for relocation to the grains (Fig. 4). Although additional nitrogen promoted leaf area development and duration and thereby the photosynthetic capacity, the content of water-soluble carbohydrates 
was decreased from 33 to $26 \%$ of the stem dry weight. The lower content of carbohydrate reserves may have been caused by a higher respiration rate and/or a greater demand of assimilates for grain growth (Höfner \& Orlovius, 1977). Austin et al. (1977) found that losses of dry matter from the stems during the post-floral period ranged from 82 to $256 \mathrm{~g} \mathrm{~m}^{-2}$ with various genotypes of winter wheat. The proportion of these losses caused by respiration was estimated to be about $62 \%$. The rate of stem respiration ranged from 0.28 to $0.35 \mathrm{mg} \mathrm{CO}_{2} \mathrm{~g}^{-1}$ dry weight $\mathrm{h}^{-1}$ at $15{ }^{\circ} \mathrm{C}$. Assuming a Q10 value of 2 for the data of Austin et al. and a mean temperature of $20^{\circ} \mathrm{C}$ in our experiment, then the stem loss due to respiration can be estimated to be about $1500 \mathrm{~kg} \mathrm{ha}^{-1}$ for the period from 29 June to 20 July. Based on this average respiration loss and with a correction of $500 \mathrm{~kg} \mathrm{ha-1}$ for translocation of carbohydrates to the roots, the contribution of stem reserves to the grains may have been in the order of 760 to $1360 \mathrm{~kg} \mathrm{ha-1}$ or 9.0 to $21.3 \%$ of the final grain yield with 200 and $50 \mathrm{~kg} \mathrm{~N} \mathrm{ha}^{-1}$, respectively. It seems that when plants are grown at a high nitrogen level, stem reserves might be less important because of the availability of more assimilates produced by the prolonged photosynthetic activity of the green tissues.

The enormous decrease in stem weight was mainly (from 80 to $85 \%$ ) due to the loss of water-soluble carbohydrates. The remaining proportion of dry weight losses may have been caused by the relocation of various compounds (proteins, amino acids, organic acids, nutrients, etc.) and, to a small extent, by lignification processes. It was estimated that the relocation of nitrogen compounds contributed from 6 to $9 \%$ of the total stem weight loss.

When all above-ground vegetative organs are considered, the nitrogen economy is as important as the carbon economy. If the nitrogen requirement of the grains exceeds the nitrogen uptake of the plant, then the nitrogen reserves in the vegetative parts will be used as nitrogen source. A fast depletion of these reserves may affect the photosynthetic activity of the leaves by an earlier senescence, thereby shortening the grain growth period (Sinclair \& de Wit, 1975). In our experiment high grain yields were associated with nitrogen contents which were higher than in normal years. This agrees with the finding in phytotron experiments that nitrogen assimilation by the grains is favoured more by warmth than is the accumulation of carbohydrate in the grains (Spiertz, 1977). The high rate of nitrogen uptake by the grains, especially during the third week after anthesis (range 0.57-0.96 $\mathrm{g} \mathrm{m}^{-2}$ day-1), required a high supply of organic nitrogen compounds. The reserves in the vegetative part could only satisfy about $52 \%$ of this demand; the other part $(48 \%)$ came from nitrogen taken up after anthesis. Such a considerable uptake after anthesis is confirmed by Sturm et al. (1973) with high-yielding wheat crops; other authors (e.g. Austin et al., 1976; Spratt \& Gasser, 1970) stated that even at anthesis the plants already contained $83 \%$ of the total nitrogen present at maturity. However, the ability of the plant to continue to take up nitrogen during the grain filling was recognized as an advantage.

Neales et al. (1963) suggested that the role of green leaves in the supply of nitrogen to the wheat grain is firstly to serve as a carbohydrate source to the roots there- 
by promoting the uptake of nitrogen, and secondly as a direct nitrogen source. The first role is enhanced if the level of soil nitrogen in the root environment during grain growth is high.

The considerable uptake of nitrogen after anthesis was also reflected in the pattern of phosphorus and potassium uptake (Fig. 6). It demonstrates that healthy wheat crops under favourable growing conditions keep up their root activity for some weeks after anthesis. The continuous uptake of phosphorus during the growth period and the loss of potassium at the ripening stage confirm the results of pot experiments with spring wheat (Slangen, 1971). Potassium is assumed to be relocated from the stem and leaves to the roots during the ripening stage. It has been stated that phosphorus is only re-distributed from the stem and not from the leaves to the grain (Slangen, 1971). However, it was concluded by Marshall \& Wardlaw (1973) that the translocation of phosphorus and photosynthate are closely related in the wheat plant; the direction of movement being governed by the supply and demand for carbohydrates. In our experiment there was relocation both from the leaves as well as from the stem (including leaf sheaths); the latter was 4 to 5 times greater.

The distribution patterns of nitrogen and phosphorus are rather similar. At harvest a major part of these nutrients was stored in the grain. Additional nitrogen dressings promoted the storage in the grains, which is illustrated by the rise in nitrogen and phosphorus harvest index from 0.75 to 0.81 and from 0.91 to 0.93 , respectively (Tabel 4). These values of the nitrogen harvest index are much higher than those quoted by Austin et al. (1976): 0.68 on average. Under Dutch growing conditions Dilz (1971) found values within the range of 0.65 to 0.75 , whilst Ellen \& Spiertz (1975) measured 0.78. Canvin (1976) reviewed data from literature and concluded that the nitrogen harvest index is subject to considerable variation, from 0.50 to 0.84 , due to factors such as water, nitrogen and carbohydrate supply. Our finding confirms the results of Gliemeroth \& Kübler (1977); they found nitrogen harvest indices of about 0.80 as a mean for three relatively dry growing seasons and of about 0.55 as a mean for unfavourable growing conditions (wet season, lodging and disease). Similar variations in nitrogen distribution were also found with spring wheat (Pearman et al., 1977). This study shows that increased nitrogen application under the prevailing growing conditions gave a higher grain yield and also a higher grain protein content. This high protein content could result from: - the positive effect of warmth on the capability of the developing caryopsis to attract and convert nitrogen (sink strength)

- a considerable capacity for uptake and assimilation of nitrogen during the grain filling period (production source)

- a high efficiency of translocation from vegetative parts to the grains (reserve source).

The rate of these processes and of photosynthesis was promoted by additional nitrogen; so high rates of starch and protein accumulation by the grains were possible. The rise in grain yield (from 640 to $821 \mathrm{~g} \mathrm{~m}^{-2}$ ) and in protein content (from 9.98 to $13.05 \%$ ) resulted in an increase of the protein yield from 63.8 to $107.1 \mathrm{~g} \mathrm{~m}^{-2}$. 


\section{Acknowledgments}

The authors wish to thank Mr J. Lettinga and Mr G. H. Heeringa of the experimental farm for their attention paid to the experiment and Dr J. H. G. Slangen for the cooperation with the chemical analyses.

The valuable comments of Dr Ir A. Darwinkel, Ir L. J. P. Kupers, Ir J. Schouls and Prof. Dr Ir G. J. Vervelde are greatly appreciated.

\section{References}

Austin, R. B., M. A. Ford, J. A. Edrich \& R. D. Blackwell, 1976. The nitrogen economy of winter wheat. J. agric. Sci., Camb. 88: 159-167.

Austin, R. B., J. A. Edrich, M. A. Ford \& R. D. Blackwell, 1977. The fate of the dry matter, carbohydrates and ${ }^{14} \mathrm{C}$ lost from the leaves and stems during grain filling. Ann. Bot. 41: $1309-1321$.

Biscoe, P. V. \& J. N. Gallagher, 1977. Weather, dry matter production and yield. In: J. J. Landsberger \& C. V. Cutting (Ed.), Environmental effects on crop physiology, pp. 75-100. Academic Press, New York.

Campbell, C. A., D. R. Cameron, W. Nicholaichuk \& H. R. Davidson, 1977a. Effects of fertilizer $\mathbf{N}$ and soil moisture on growth, $\mathrm{N}$ content and moisture use by spring wheat. Can. J. Soil Sci. 57: 289-310.

Campbell. C. A., H. R. Davidson \& F. G. Warder, 1977b. Effects of fertilizer N and soil moisture on yield, yield components, protein content and $\mathbf{N}$ accumulation in the aboveground parts of spring wheat. Can. J. Soil Sci. 57: 311-327.

Canvin, D. T., 1976. Interrelationships between carbohydrate and nitrogen metabolism. In: Genetic improvement of seed proteins, pp. 172-190. National Academy of Sciences, Washington D.C.

Dalling, M. J., Gerardine Boland \& J.H. Wilson, 1976. Relation between acid proteinase activity and re-distribution of nitrogen during grain development in wheat. Aust. J. Pl. Physiol. 3: 721-730.

Dilz, K., 1971. Effects of time of chlormequat application, level of nitrogen and split application of nitrogen on resistance to lodging and on yield of winter wheat. Neth. Nitrogen tech. Bull. No 10, pp. 40.

Ellen, J. \& J. H. J. Spiertz, 1975. The influence of nitrogen and benlate on leaf area duration, grain growth and pattern of N-, P- and K-uptake of winter wheat (Triticum aestivum). Z. Acker- u. PflBau 141: 231-239.

Evans, L. T. \& I. F. Wardlaw, 1976. Aspects of the comparative physiology of grain yield in cereals. Adv. Agron. 28: 301-359.

Ford, M. A. \& G. N. Thorne, 1975 Effects of variation in temperature and light intensity at different times on growth and yield of spring wheat. Ann. appl. Biol. 80: 283-299.

Gallagher, J. N., P. V. Biscoe \& B. Hunter, 1976. Effects of drought on grain growth. Nature 264 (9 December) 541-542.

Gliemeroth, G. \& E. Kübler, 1977. Ertragsaufbau von Winterweizen bei unterschiedlich aufgeteilten Stickstoffmengen in Abhängigkeit vom $\mathbf{N}$-mineralisationsvermögen pseudovergleyter Parabraunerden. Z. Acker- u. PflBau 144: 165-186.

Höfner, W. \& K. Orlovius, 1977. Einfluss der N-düngung auf den ${ }^{14} \mathrm{C}$-Einbau in die Komponenten der äthanollöslicher Fraktion von Sommerweizen verschiedener Entwicklungsstadien. Z. PflErnähr. Bodenkd. 140: 591-504.

Langer, R. H. M. \& F. K. Y. Liew, 1973. Effects of varying nitrogen supply at different stages of the reproductive phase on spikelet and grain production and on grain nitrogen wheat. Aust. J. agric. Res 24: 647-656.

Marshall, C. \& I. F. Wardlaw, 1973. A comparative study of the distribution and speed of 


\section{J. H. J. SPIERTZ AND J. ELLEN}

movement of ${ }^{14} \mathrm{C}$-assimilates and foliar-applied ${ }^{32} \mathrm{P}$-labelled phosphate in wheat. Aust. J. biol. Sci. 26: 1-13.

Meredith, P. \& L. D. Jenkins, 1976. The developing starch granule. 3 The filling of the wheat grain. N.Z. Jl Sci. 19: 115-123.

Neales, T. F., M. Jean Anderson \& I. F. Wardlaw, 1963. The role of leaves in the accumulation of nitrogen by wheat during ear development. Aust. J. agric. Res. 14: 725-736.

Pearman, I., Susan M. Thomas \& Gillian N. Thorne, 1977. Effects of nitrogen fentilizer on growth and yield of spring wheat. Ann. Bot. 41: 93-108.

Sinclair, T. R. \& C. T. de Wit, 1975. Photosynthate and nitrogen requirements for seed production by various crops. Science 189: 565-567.

Sofield, I., L. T. Evans \& I. F. Wardlaw, 1974. The effects of temperature and light on grain filling in wheat. In: Mechanisms of regulation of plant growth. Bull. Royal Soc. N.Z. 12: 909-915.

Slangen, J. H. G., 1971. Intermitterende voeding bij tarwe. Thesis, Agricultural University, Wageningen, pp 130.

Spiertz, J. H. J., 1974. Grain growth and distribution of dry matter in the wheat plant as influenced by temperature, light energy and ear size. Neth. J. agric. Sci. 22: 207-220.

Spiertz, J. H. J., 1977. The influence of temperature and light intensity on grain growth in relation to the carbohydrate and nitrogen economy of the wheat plant. Neth. J. agric. Sci. 25: 182-197.

Spratt, E. D. \& J. K. R. Gasser, 1970. Effects of fertilizer, nitrogen and water supply on distribution of dry matter and nitrogen between the different parts of wheat. Can. J. Pl. Sci. 50: 613-625.

Stoy, V., 1975. Assimilatbildung und -verteilung als Komponenten der Ertragsbildung beim Getreide. Angew. Bot. 47: 17-26.

Sturm, H., W. Zwick \& H. Lang, 1973. Perspektiven der Nährstoff-Versorgung einschliesslich Wachstumregulatoren im intensiven Getreidebau. BASF Mitt. Landbau 3: 91-121.

Warrington, I. J., R. L. Dunstone \& L. M. Green, 1977. Temperature effects at three development stages on the yield of the wheat ear. Aust. J. agric. Res. 28: 11-27. 